Article

\title{
Now You See Me? The Visibility of Trans and Travesti Experiences in Criminal Procedures
}

\author{
Lorena Sosa \\ Netherlands Institute of Human Rights, Utrecht University, 3584 BH Utrecht, The Netherlands; E-Mail: I.p.a.sosa@uu.nl
}

Submitted: 15 January 2020 | Accepted: 10 June 2020 | Published: 18 September 2020

\begin{abstract}
In 2012, after decades of trans and travesti activism in Argentina, the law on gender identity was finally adopted. Travesti activists Diana Sacayán and Lohana Berkins were at the forefront of these efforts. The same year, after the long struggle of the feminist movement, 'femicide,' understood as the murder of women by men in the context of gender-based violence, was incorporated into the Criminal Code as aggravated murder. This legal amendment also criminalized hate crime based on the sexual orientation or gender identity of the victim. Mobilized by Sacayán's murder in 2015, the trans and travesti collective sought to make the experiences of exclusion and marginalization of the travesti collective visible by coining the notion of 'travesticide,' and demanded it to be used in the ensuing criminal trial that followed her death. Constrained by the legal notions of femicide, gender-based violence, and hate crimes, the Tribunal introduced 'travesticide' in their decision, yet questions on how to properly operationalize this notion in criminal law remain. Each notion offers opportunities and poses difficulties in making the murder of travestis politically visible and accounted for. By a detailed analysis of the final judgment, this article reflects on the implications of the notions used in the trial and the possible lessons for future interactions with the criminal justice system.
\end{abstract}

\section{Keywords}

Argentina; criminal procedures; femicide; gender identity; hate crime; transgender; travesti; travesticide

\section{Issue}

This article is part of the issue "Trans* Politics: Current Challenges and Contestations" edited by Mieke Verloo (Radboud University, The Netherlands) and Anna van der Vleuten (Radboud University, The Netherlands).

(C) 2020 by the author; licensee Cogitatio (Lisbon, Portugal). This article is licensed under a Creative Commons Attribution 4.0 International License (CC BY).

\section{Introduction}

Trans persons and travestis in the Americas have articulated numerous social collectives to fight against the persistent subordination and injustices they face. Likewise, in Argentina, travestis successfully organized and advocated for their rights. In doing so, assuming the 'travesti identity' was a first step to making their demands visible, triggering a powerful dynamic of self-naming, recognition and mobilization. Yet what does 'travesti' entail and how is it different from 'transgender'?

As Santana (2019, p. 212) points out, "travesti does not correspond to the English travesty [transvestite], which is related somewhat to a performance in drag." Identifying as travesti entails "the refusal to be woman, the refusal to be intelligible," but also "the refusal to be trans" (Machuca Rose, 2019, p. 243), since the travesti identity goes beyond gender. Unlike the English 'transgender,' 'travesti' articulates aspects of race, class, ability, and other forms of difference (Rizki, 2019, p. 148). Thus, as Santana (2019, p. 213) explains, being travesti "is not a total negation of themselves as women but a negation of an imposed dominant expectation of womanhood." The travesti identity seeks to elude the identity categories constructed by a state system of social oppression (Berkins, 2003, p. 136). In fact, travesti politics evoke the historical marginalization of the collective, one with clear racial, able-bodiedness, and elitist undertones. Diana Sacayán's self-identification as 'trava sudaca originaria' helps underscore the different dimensions of her travesti identity. By focusing on Diana's murder trial, this article pays particular attention to the 
travesti identity, yet, in line with Rizki (2019), it also recognizes that trans and travesti identifications are constantly shifting and thus, it does not immediately assume they are mutually exclusive (Rizki, 2019, p. 149), but separate.

The visibilization of travesti realities has triggered a considerable number of reforms across different legal and policy realms. Among them, criminal law constitutes a crucial battlefield for such change given the historical criminalization of trans/travestis under repressive police codes (Berkins, 2007; Fernández Valle, 2018). In fact, the first travesti association, the Association of Argentine Travestis (in Spanish, ATA), was formed in 1991 to fight police brutality and abuse, gradually leading to the abolition of the most repressive norms. Nevertheless, the trans/travesti collective continues to be disproportionately affected by new forms of persecution, such as the criminalization of the promotion of sex work (Fernández Valle, 2018, p. 50; Sosa \& Ferrero, 2018) or drug trafficking (Malacalza, 2018).

However, (trans) feminisms in Latin America, and also in Argentina, have often been ambivalent regarding the use of the punitive system to address issues that reveal structural inequality and disadvantage, since it cannot solve these issues and in fact, because it is rooted in a patriarchal structure, it often sustains the criminalization of the most affected sectors of society (Zaffaroni, 2000). At the same time, there has been a tendency towards increased criminalization, particularly in relation to severe forms of violence against women and feminine subjectivities (Acosta Vargas, 1999; Costa, 2014).

Aware of these tensions regarding punitivism, making trans/travestis' experiences visible in the criminal fora and translating them into demands could challenge their persistent profiling as suspects of crime and reconfigure them as subjects of protection, transforming both criminal and criminological discourse. The trial for the murder of trans activist Diana Sacayán offered a perfect scenario to do this. This article explores how the main (historical) demands of the trans and travesti community in Argentina, explored in Section 2, were reconfigured and introduced in the criminal proceedings. Section 3 discusses the final judgment in detail by examining the position of each of the parties to the trial in relation to the key aspects described in Section 2, and how these were interpreted by the judges in relation to the elements of the crimes. Section 4 reflects on the findings and highlights the positive aspects for similar strategic litigations, and draws attention to some problematic areas.

\section{Historical Claims of the Trans/Travesti Community and Institutional Responses}

There have been three main historical claims of the travesti and trans community in Argentina: the legal recognition of their preferred gender; the possibility to decide on their bodies; and the accountability for their murder.

\subsection{Legal Gender Identity}

The campaign for the legal recognition of the selfperceived gender identity in Argentina articulated demands about social positioning, participation, and the fight against the violations of rights. Until recent times, Argentinian media regularly portrayed travestis as a dangerous threat to 'moral society.' Assuming the travesti identity became an act of resistance, followed by mobilization and alliance making as a main political strategy (Berkins, 2003). This led to the creation of several associations, such as the already mentioned ATA, the Association for the Fight for Travesti Transsexual Identity (led by Lohana Berkins) and the Organization of Travestis and Transsexuals of Argentina. In this process, the term 'travesti' achieved a new and empowering meaning, cleared from the negative connotation given by the police (Berkins, 2007).

Gender identity demands sought to consolidate this process and ensure the enjoyment of human rights. The lack of legal recognition of gender identity signified the starting point of a continuum of violence and systematic violations of basic rights, such as the expulsion from the home, the education, the health system, and the labour market, leading travestis to sex work and exposing them to health risks, criminalization, social stigma, and police abuse (Radi \& Pecheny, 2018). The legal recognition of gender identity, thus, makes the enjoyment of other rights possible, giving citizenship and democratic participation a new meaning (Berkins \& Fernandez, 2005; Cabral Grinspan \& Viturro, 2006; Pecheny \& De la Dehesa, 2011; Radi \& Pecheny, 2018; Rapisardi, 2003).

The demands for the legal recognition of gender identity began to take shape in the first decades of 2000, with the formation of the Anti-Discrimination Liberation Movement (MAL, led by Diana Sacayán), the Argentinian LGBT Federation (FALGBT), and the National Front for the Gender Identity Law. The National Front for the Gender Identity Law and FALGBT prepared a draft law on Gender Identity, which was finally adopted in 2012 as Law 26.743 . The law entitles a person to change their sex and name in an administrative proceeding, without requiring medical or psychological advice or body intervention, and recognizes the person's right to undergo therapy, treatments or surgeries, provided by the State. The implications of the law on bodies are discussed in Section 2.2.

The law was celebrated by trans activists and allies, but it was also critiqued by travesti activists because it upholds the binary construction of the sexes as men/women, "cancelling out the travesti or trans identity" (Wayar, 2012). Nevertheless, as de Mauro Rucovsky and Russell (2019, p. 224) point out, the law has become "a political toolbox rather than a mere legal instrument," which has impacted the interpretation of other laws, including criminal law as we shall see, and it has also helped to disrupt the binary construction of gender identities by, for instance, allowing registries and courts to grant identity documents without gender indi- 
cation. These challenges to binary sex were also present in the most recent annual feminist meeting-'Encuentro Nacional de Mujeres' (gathering thousands of women every year)-calling for a new name that explicitly includes trans/travesti subjectivities and realities. They have also been institutionally supported by the creation of the national ministry for 'Women, Genders and Diversities.'

To some extent, Law 26.743 also contributed to the realization of basic substantial rights, such as the right to education, health, housing, and work. This has been particularly the case for younger generations (Saldivia Menajovsky, 2018), yet the adult trans/travesti community has not experienced substantial changes and have limited access to basic human rights due to insufficient implementation (Korol, 2018; Viturro, 2014).

\subsection{Body Sovereignty}

According to Fernández (2003), the visibilization gained during the 1990s provided an opportunity to question the sex/gender binary and the social construction of bodies and sexes. 'Travesti bodies' are seen as cultural, social, and political objects (Fernández, 2003, p. 147) that confront the oppressive western construct 'man/woman' (Berkins, 2007). Laws have controlled and disciplined their bodies in different ways. Social rejection and institutional harassment, particularly by the police, are ways of disciplining travesti bodies that do not comply with dominant appearances, either because the lack of resources prevents them from accessing the technologies to change their bodies or because they are comfortable with their own embodiment.

Restricting the possibility to change one's gender attributed at birth is another way of policing bodies. Before the adoption of Law 26.743, the 'real' gender of an adult person was determined by judges with the advice of different medical disciplines, regardless of the person's will. The law stripped judges and doctors from such power and gave it back to the individual. Since then, the person is free to determine their gender identity in a simple administrative procedure free of charge.

Moreover, the approach of Law 26.743 towards body intervention is one of rights rather than requirements. Article 11 substantiates the right to a "free personal development" (Ministerio de Justicia y Derechos Humanos, 2012a) ensuring that every person older than 18 can access surgery or hormonal treatments to adapt their bodies to their perceived gender identity, without any judicial or administrative authorization. This approach discourages binary and hegemonic depictions of bodies and, importantly, it entails the legal recognition of the person's 'sovereignty' on their own bodies, a longstanding demand of the trans/travesti community. The institutional cultures, however, show difficulties in accommodating the new law since the medical and judicial practices of requiring physical and psychological examinations are deeply rooted, and so are hegemonic and binary views of bodies.

\subsection{Murder Accountability}

Trans/travesti and feminist activists in Argentina have also demanded accountability for gender-based murders for decades. Different conceptualizations have emerged in that process, each carrying different symbolic and legal implications. This section discusses the conceptualizations (femicide, travesticide, and hate crime) that are relevant to fully understand the final judgment on Diana Sacayán's murder, their theoretical and symbolic meaning, and their legal implications.

\subsubsection{Femicide and Travesticide}

The visibilization of femicide relates to a historical and social process of recognition of the human rights of women and their right to a life free from violence. The theoretical concept of 'femicide' made the systematic murder of women visible. It was defined by Radford and Russell (1994) as the killing of women perpetrated by men and elaborated further by Lagarde (2006) to underline the gendered nature of the killings and the social constructs behind them. The notion was introduced in shadow reports, amicus curiae briefs, and individual petitions before the Inter-American Human Rights System (IAHRS). In 2008, the Committee of Experts monitoring the InterAmerican Convention on the Prevention, Punishment, and Eradication of Violence against Women adopted the Declaration on Femicide (Mechanism to Follow Up Convention of Belém do Pará Committee of Experts on Violence, 2008), and the Inter-American Court on Human Rights (IACtHR) recognized it in González et al. v. Mexico ('Cotton Field'). In Argentina, Casa del Encuentro, a feminist association, published the first report on femicides the same year.

These demands resulted in the adoption of Law 26.485 in 2009 on the integral protection of women from violence and the amendment of the Criminal Code by Law 26.791 in 2012 on gender-based crimes. The amendment to the Criminal Code consisted of introducing new aggravations to murder in Article 80, capturing the gender-based nature of the crimes. It explicitly criminalized the murder of "a woman, committed by a man in a situation of gender-based violence" (Ministerio de Justicia y Derechos Humanos, 2012b, Article 80.11), commonly referred to as 'femicide' in all prosecutorial guidelines, protocols, doctrine, and the media. The introduction of these aggravations follows the regional tendency, encouraged by the IAHRS, to adopt gender specific definitions of crimes as an attempt to making visible the structural power imbalances that underlie such crimes. Gendered definitions of crimes send a strong message that such violence is unacceptable, challenging gender stereotypes that view violence as natural and belonging to the private sphere. Yet, the question arises whether, beyond such symbolic meaning, gender specific crimes help in preventing impunity and improve access to justice. In principle, they contribute to collect disaggregated 
criminal statistics, revealing the prevalence of such violence and adopting more effective policy measures.

Adopting a gendered definition of femicide, however, did not per se yield significant changes in practice. In fact, in 2015, the impunity of violence against women and girls in Argentina reached unprecedented levels, triggering social uproar. This year would become a milestone for several reasons. On June 3rd, 2015, a massive nation-wide demonstration against the murder of women took place, setting in motion an organized movement that expanded to other countries in the Americas-the \#NiUnaMenos movement-actively supported by Diana Sacayán and Lohana Berkins.

These demonstrations resulted in two institutional changes. The first was the creation in 2015 of the Prosecution Unit for Violence Against Women (UFEM), which dictates prosecution protocols and publishes annual reports on the murders of women in the city of Buenos Aires. The second development was the decision of the Supreme Court of Justice (SCJ) to formally record femicides and issue a nationwide annual report on such cases. These recording initiatives ensure the visibility of the murder of women.

Yet, the murder of trans women and travestis seem to call for a conceptual twist of the theoretical notion of femicide and its current criminal 'translation' for two reasons. Firstly, the official reports on femicide and protocols suggest that the inclusion of trans and travesti victims as 'women' has not always been consistent, showing the limitations of the Gender Identity Law and bringing to question whether the current notion of femicide truly increases access to justice and fights impunity. For instance, the UFEM reports interpret 'women' in line with the Gender Identity Law and include all female subjectivities regardless of their gender assigned at birth, the formal registration of their gender identity, or how they were identified in the criminal process. However, the criminal framing of their murder has shifted through the years, sometimes referring to them as homophobic and transphobic femicide, sometimes as hate crimes (UFEM, 2015) and, more recently, as travesticide (UFEM, 2018). The SCJ annual reports on femicide include trans and travesti victims only since 2018 (Corte Suprema de Justicia de la Nacion, 2018). The current gender-specific crime of femicide, thus, even if read in line with the Gender Identity Law, does not fully ensure the visibility of trans and travesti.

Secondly, despite existing protocols, national jurisprudence suggests that the requirement that the crime was committed 'in a situation of gender-based violence' is often (mis)interpreted as calling for the perpetrator to be the intimate partner (intimate femicide) and the victim in a subordinated position in relation to the perpetrator. Such understanding of 'genderbased violence' does not meet the demands of Radi and Sardá (2016), who argue that a definition of transfemicide/travesticide must reflect that murder is the most visible and final expression in a long chain of struc- tural violence encouraged by a cultural, social, political, and economic system, structured around the gender binary. The murder of trans/travestis constitutes, in fact, the end of a continuum of violations they face. To achieve any symbolic impact, the criminal definition must capture the specificity of these experiences.

\subsubsection{Hate Crime}

The 2012 amendment that incorporated femicide to the Argentinian Criminal Code also incorporated sexual orientation and gender identity (SOGI) to the list of grounds aggravating murder based on 'hate' (Ministerio de Justicia y Derechos Humanos, 2012b, Article 80.4). The recognition of hate crimes, however, shows a very different trajectory at the national level than that of femicide or gender identity. Although such incorporation is in line with the recommendation of the InterAmerican Commission of Human Rights (IACHR, 2015, p. 270) to "enact hate crimes legislation to identify, prosecute, and punish prejudice-based violence against persons due to perceived or actual sexual orientation and gender identity," debates on hate crimes based on SOGI have not been prominent in Argentina. In fact, although LGBT movements in other countries have promoted hate crime as a political and legal tool for addressing violence against the collective, the trans/travesti movement in Argentina did not follow that line. Nevertheless, the Homosexual Community of Argentina started issuing annual reports on hate crimes in 2011, dedicating their 2015 Report to Diana Sacayán. In 2016, the Office of the Public Defence of Buenos Aires, the National Office of Public Defence, and the LGBT Federation formed a National Observatory for LGBTI Hate Crimes.

Despite the incorporation of hate crimes based on SOGI to the Code, there have been very few judicial cases, particularly on transphobic hate crimes, and there is consequently scarce national doctrine elaborating on their defining characteristics. An overview of their key aspects, however, is needed to assess the potential of the hate crimes for making trans murders visible and challenge impunity.

Regarding the visibility of the trans/travesti community, a relevant aspect of hate crimes is that perpetrators target the victims' (perceived) belonging to a given group, not their individual traits (Craig, 2002; Gerstenfeld, 2004; Mcphail, 2012; Perry, 2012). In fact, Perry and Alvi (2011) argue that hate crimes are symbolic acts performed for specific audiences, where the perpetrator sends a message to the group that they are unwelcome and that any group member could be the next victim. Most definitions of hate crime, thus, revolve around the group affiliation of the victim, yet only a few of them emphasize the disadvantaged social positioning and marginalization of victims and groups (Copeland \& Wolfe, 1991; Perry, 2012; Sheffield, 1995). Nevertheless, group-based definitions often "tend to oversimplify victim groups and do not take into account the diverse 
experiences of victims and the nuances of the harms they suffer" and prevent an intersectional understanding of their identities (Mason-Bish, 2014, p. 42). In relation to trans persons, in particular, Meyer (2014, p. 122) holds that mainstream hate crime discourse "aligns the victim's identity with normative conceptions of homosexuality," therefore representing victims in a gendered and racialised manner, implicitly assuming that victims of hate crimes are white middle-class gay men, hiding other aspects and victims. The potential of hate crime for making violence against trans/travestis visible will thus largely depend on how group belonging is framed and how victims are perceived.

Aspects connected to the subjective element of the crimes may, in practice, jeopardize the prosecution and punishment of the violence. Firstly, most definitions of hate crime focus on the perpetrator's bias ('hate') against the victim (Zaffaroni, 2007). This means that, in addition to the intent to commit the crime, hate crimes require a specific motivation behind their commission (Figari, 2018; Hall, 2013; Jacobs \& Potter, 1998; Juárez, n.d.; Zaffaroni, 2007), which puts an additional burden on prosecutors and the police that need to prove it (Hall, 2013). There is also much dissent among scholars on what the motivation is. Hall $(2013$, p. 9) argues that it is 'prejudice' and not hate that we refer to when we talk about hate crime. The IACHR $(2015$, p. 44) specifies this further, suggesting that hate crimes consist of "prejudice motivated by the perception towards non-normative sexualities and identities." Jamel (2018), however, suggests that transphobic hate crimes convey the offender's 'fear' of trans people based solely on their physical appearance. Argentinian scholars like Buompadre (2013) and Figari (2018) argue that hate crimes are characterized by an 'extreme aversion' of the perpetrator against the victim's group belonging. Each of these understandings of 'hate' suggests a different intensity of the bias and have evidence-related implications. For instance, Figari (2018, p. 16) suggests that 'aversion' is so strong that it calls for a psychological assessment to rule out any potential exclusion of culpability due to mental and emotional conditions.

Secondly, the way the causal link between prejudice and the commission of the crime is defined by law will also determine the number of cases prosecuted. If norms require hate crimes to be only motivated by prejudice to the exclusion of all other factors, fewer offences will be recorded. According to Figari (2018, p. 9), Argentinian law requires this connection. Conversely, if the causal link is less strict and allows for other additional factors, e.g., economic interest, more offences will fall under the category (Jacobs \& Potter, 1998, p. 33).

Some aspects connected to the material elements of hate crimes may prolong the impunity of some forms of violence against trans/travestis. Hate crimes often show high levels of cruelty that exceed the instrumental purpose of submitting the victim, particularly those against LGBT persons (IACHR, 2015). For some authors, this 'overkill' constitutes an objective element of the crime (Hall, 2013; Jamel, 2018) that must be backed by evidence, which means that crimes lacking such brutality will not be prosecuted as hate crime. Moreover, hate crime is usually associated with severe offences only, excluding minor forms of violence (Meyer, 2014). In Argentina, transphobic hate only aggravates murder or severe bodily injuries, which means that other forms of violence committed against trans/travestis, including sexual violence and property crimes, will receive a 'regular' punishment with no indication of the motivation behind them.

Despite the limitations of the crime of femicide and hate crimes based on gender identity to make travesti experiences visible described in these sections, the new draft Criminal Code submitted to Congress in May 2019 keeps the wording of Article 80 ("murder of a woman by a man" and "hate based on gender identity"; Ministerio de Justicia y Derechos Humanos, 2012b) intact.

The next section explores the potential of the current framework to address these three historical trans/travesti claims in the criminal justice context.

\section{The Diana Sacayán Case}

\subsection{Introduction to the Case}

Diana Sacayán's body was found gagged and with bound hands and feet in her apartment in Buenos Aires on July 13th, 2015. Her body had multiple cuts and bruises, and knives were found on the scene. The perpetrators forced the front door from the inside to escape. A man with whom she had an intimate relationship was charged with her murder.

As mentioned, Diana Sacayán was a prominent activist, trans human rights defender, representative of the International Lesbian, Gay, Bisexual, Trans and Intersex Association, and founder of the MAL. She also worked at the National Anti-discrimination Institute (INADI). Diana was the first person to change her gender identity after the adoption of the Gender Identity Law and successfully advocated for the adoption of trans quotas in the public sector and a protocol for trans-specific public health care in Buenos Aires. She had an established media presence. Her death severely affected the LGBT community in Argentina. Diana's family and civil society organizations mobilized after her death and formed a commission called 'Justice for Diana Sacayán/End travesticide' ('the Justice Commission'). The Commission actively engaged with the media, raising awareness and seeking social support. There was regular media reporting on the case, with the collaboration of experts and activists.

There were four main acting parties in this case: the defence, the main prosecutor, and two auxiliary prosecutors, one on behalf of the INADI and another on behalf of Diana's brother. In addition, the UFEM (supported by the Justice Commission) acted as advisor to the main prosecutor. The unusual number of persons involved in 
the trial reflects the public interest it evoked. Prior to the final judgment, the head of the UFEM described in an interview the role of the Justice Commission in relation to the prosecutorial strategy in the case: "The construction was a collective one, with the family and the organizations. They [the Commission] asked for things that forced us [the prosecutors] to reconsider some notions. They voiced their concerns, we responded" (Revista Institucional de la Defensa Pública, 2018, p. 337).

\subsection{Main Arguments of the Parties}

The parties based their arguments on a combination of theoretical conceptualizations and legal notions, some in unison and some diverging.

\subsection{1. 'Travesticide' as a Theoretical Notion and Means of Visibility and Recognition}

This trial introduced the term travesticide in a judicial procedure for the first time and brought it to the attention of the media. The Commission emphasised two aspects. Firstly, although gender-based violence is common to femicides and the murder of travestis, 'travesticide' aimed at capturing the specificities of such murders. Second, it attempts to make visible the structural vulnerability, marginality, and systematic violence affecting the majority of trans/travestis. These two aspects lie at the core of the notion, and in a way, comprises all claims described in the previous section.

All prosecutorial parties agreed that the notion of 'travesticide' fleshes out the historical and structural discrimination against trans/travestis and their exposure to violence throughout their lives (Poder Judicial de la Nación, 2018, p. 174). Yet, how to frame in criminal law a murder theoretically conceptualized as travesticide? Article 80 of the Criminal Code (Ministerio de Justicia y Derechos Humanos, 2012b) offers the chance to criminalize the murder as a hate crime based on the sexual orientation or gender identity (Section 4 of Article 80), and/or as 'femicide,' the murder of a woman by a man in a context of gender-based violence (Section 11 of Article 80).

\subsubsection{Travesticide as a Hate Crime}

All parties considered that travesticide fell under the aggravation of hate crime based on gender identity and that this judgment was an opportunity to fill the doctrinal gap on such crimes in Argentina. In their oral pleadings, the prosecutorial parties followed the guidelines of the 2015 Report on violence against LGBTI persons by the Inter-American Commission-the IAC Report-to assess the scope and evidentiary requirements for hate crimes.

The prosecutorial parties highlighted the structural and discriminatory nature of the violence against trans/travestis (Poder Judicial de la Nación, 2018, pp. 29, $32,37)$, in line with Perry's (2012) socio-structural ap- proach to hate crime and the IAC report. They introduced official reports and experts' testimonies as evidence, and more importantly, the testimonies of the trans community regarding their life experiences. They also provided long and detailed accounts of Sacayan's life, paralleling those of the trans community, a strategy also used by the IACtHR in its judgments on femicide (Celorio, 2010; Sosa, 2017). The UFEM emphasized the relevance of the structural context and its legal implications, particularly in relation to reparations.

Regarding the type of motivation that falls under 'hate,' the INADI and the main prosecutor considered it refers to the "aversion" against a person or group of persons (Poder Judicial de la Nación, 2018, pp. 32, $54)$, suggesting a threshold higher than that for "prejudice." The prosecutor argued that such aversion was triggered by the victim's characteristics (Poder Judicial de la Nación, 2018, p. 54), while the INADI considered it resulted from the "contradiction between desire and rejection of the travesti body" (Poder Judicial de la Nación, 2018 , p. 25). However, they did not explain the connection between the aversion of the abuser and the context of discrimination and exclusion, thus contributing to the idea that such murders are incidental and the product of one individual.

The INADI and the defence lawyer agreed that although the "aversion" belongs to the internal process of the abusers, it shows in their actions and other explicit or symbolic manifestations (Poder Judicial de la Nación, 2018 , p. 33). The derogative comments by the mother or acquaintances of the accused about trans persons could constitute an indication of the aversion, the prosecutor argued. The defence lawyer refused, however, arguing that only the personal manifestations of the accused could prove his aversion against travestis and, thus, additional evidence was needed (Poder Judicial de la Nación, 2018, p. 120).

\subsubsection{The Relevance of Bodies in Travesticide}

The INADI emphasised that the abuser could either "leave a message on the walls or on the victim's body" (Poder Judicial de la Nación, 2018, p. 33). For all parties, the victims' bodies can indicate the special aversion of the abuser, the intention to humiliate the victim, and the rejection of her identity, proving the subjective element of hate crimes (Poder Judicial de la Nación, 2018, pp. 22, $35,44)$. Diana's body thus became the main evidence of 'hate.' The three prosecutorial parties agreed that the wounds on her breasts, buttocks, and face could prove the aversion of the abuser (Poder Judicial de la Nación, 2018, pp. 22, 52, 55).

The connection between the definition of the crimes and the overkill (high levels of brutality) determines the level of violence travesti bodies are expected to have suffered. For instance, the INADI considered that the overkill was an inherent element of hate crimes, manifested in victims' bodies (Poder Judicial de la Nación, 
2018, p. 38). This implies that, in his view, these crimes require excessive violence, even if the result is murder. The defence lawyer agreed with him and added that the IACHR illustrated 'overkill' with examples of extreme (sexual) violence, such as decapitation, multiple ejaculations on bodies, etc. (Poder Judicial de la Nación, 2018, p. 114). He then argued that the level of violence displayed by Diana's body did not meet the required level of severity, and that her wounds corresponded to weapons used (knives) and her defensive behaviour (Poder Judicial de la Nación, 2018, p. 115).

Conversely, the victim's representative disagreed with the inherent character of the overkill, arguing that such excessive violence would in fact constitute an additional aggravation of the crime, falling under Article 80.2 (Poder Judicial de la Nación, 2018, p. 22). Under this approach, murders which are not exceedingly brutal could still constitute hate crimes, and the instrumental role of travesti bodies could be circumvented, along with the severe scrutiny they are subjected to.

\subsection{4. (Trans)femicide}

Both auxiliary prosecutors understood that the murder of Sacayán also fell under the aggravation of femicide (Article 80.11; Ministerio de Justicia y Derechos Humanos, 2012b) since according to the Gender Identity Law she was a woman, and the crime was committed in a context of gender-based violence. In fact, all prosecutorial parties considered that Diana's gender identity was enough justification to frame the crime as femicide, without elaborating on the objective element-the situation of gender-based violence. The prosecutor suggested the subordinate position was evident "between a man and a woman" (Poder Judicial de la Nación, 2018, p. 39). Such a position, however, does not underscore the structural context of violence against trans/travestis. Particularly since the defence lawyer challenged the classification of the crime as femicide because, he argued, Diana was not in a subordinated position. "She appears as a political referent of LGBTI organizations, speaking in International fora, with a large network. [The suspect] is a shy boy, who keeps silent in meetings, lives with his mother, has never been heard uttering a gender-violence type of expression, and has no previous record in that sense" (Poder Judicial de la Nación, 2018 , p. 130). Elaborating on how gender-based violence transcends inter-personal relationships, thus intimate femicide,' and how this can be proved in court helps to capture the structural violence and discrimination that trans/travestis face.

In addition, the main prosecutor considered that the aggravation of femicide applied only subsidiarily if hate crime is ruled out (Poder Judicial de la Nación, 2018, pp. 58,61$)$. This raises the question of whether victims' identities can be considered from an intersectional perspective if their deaths can only be framed either as a hate crime or femicide.

\subsection{The Final Judgment: Between Travesti Demands and the Letter of Criminal Law}

The tribunal, comprised of three judges, sentenced the accused to life imprisonment for the murder of Diana Sacayán, aggravated by Article 80.4 (hate based on gender identity) and Article 80.11 (femicide; Ministerio de Justicia y Derechos Humanos, 2012b). The 414 page-long decision features the reasoning of Judge Calvete (chair), Judge Baez, and the dissenting opinion of Judge Bloch. Their combined argumentations clarify important legal aspects of the violent murder of trans/travestis raised by the parties, notably, the possibilities to capture the sociostructural nature of such violence in criminal law and evidence-related aspects of transphobic hate crimes.

\subsubsection{Criminal Law and Socio-Structural Perspectives on Violence}

Perhaps the most notable aspect of the judgment is the judges' recognition of the structural nature of the discrimination and violence against trans/travesti, with clear references to the continuum of violence they suffer (Poder Judicial de la Nación, 2018, p. 381). The statistics, reports, and testimonies helped in shaping this new dimension. The judges' depiction of Diana throughout the judgment, informed by the vivid testimonies, went beyond the typical victim profiling and emphasized the parallel with the lived realities of travestis. This acknowledgment includes the institutional dimension of the violence. Judge Bloch admitted that violence is often committed by public institutions, particularly by the police (Poder Judicial de la Nación, 2018, p. 314). She also underscored that the lack of an investigation and prosecution leads to the invisibility of the violence and explains the lack of jurisprudence on transphobic hate crime despite the high prevalence of transphobic violence (Poder Judicial de la Nación, 2018, p. 379).

All judges recognized that the conceptual use of 'travesticide' reveals the complex structural dimension of the violence affecting trans women. Bloch suggested that it should be possible to introduce "as many names as there are types of hatred and subjectivities," if it helps in making an existing problem more visible (Poder Judicial de la Nación, 2018, p. 387). Calvete saw "no obstacle to its forensic usage" if it helps clarify the case at hand (Poder Judicial de la Nación, 2018, p. 174). That said, Bloch pointed out that there are alternatives for legally framing travesticide-as hate crime (Article 80.4), but also as femicide (Article 80.11) when the victim is a trans woman ('transfemicide'; Poder Judicial de la Nación, 2018, p. 388). However, Calvete and Báez, like the prosecutors, seemed to consider that 'hate crime' was the only possible framing, which in practice may lead to overlooking the socio-structural nature of the violence against travestis (Poder Judicial de la Nación, 2018, pp. 175, 214).

Judge Bloch reveals the first challenge that hate crimes pose to structural understandings of violence 
by highlighting that the legal definition of hate crimes does not seek to protect groups facing structural discrimination, as the prosecutor argued (Poder Judicial de la Nación, 2018, p. 372). The judges agreed that hate crimes are defined by the motivation of the abuser, rather than the characteristics or group belonging of the victim. It constitutes a hate crime when the abuser murdered because of his aversion based on the gender identity of the victim, regardless of whether the victim was really trans/travesti (Poder Judicial de la Nación, 2018, pp. $173,307,325,365)$. Hate crimes, Bloch argued, are more severely sanctioned because they infringe on the autonomy of the victim and other members of the 'protected' group in addition to the primary violation (against life, physical integrity, sexual autonomy, property, etc.). That "individual liberty," she argues, is precious to all democratic systems (Poder Judicial de la Nación, 2018, pp. 316, 317). The second challenge arises precisely from the legal conceptualization of 'hate' as 'aversion.' In line with Figari (2018), Calvete explains that aversion points to an individual motivation of a psychological nature, in opposition to that in 'femicide,' which is "cultural or sociological" (Poder Judicial de la Nación, 2018, p. 171). Could hate crime ever capture the socio-structural understanding of travesticide, even when all judges have acknowledged it?

The judges' discussion regarding femicide and the meaning of 'gender-based violence' also raises questions regarding its usefulness to capture socio-structural perspectives. All judges agreed that trans women and travestis constitute 'women' in the meaning of the law. They agreed to a large extent about the nature of genderbased violence. Judge Baez critiqued the legislative technique that establishes that only a man can be the perpetrator of femicide and a woman the victim (Poder Judicial de la Nación, 2018, pp. 272-274), yet he recognised that, in line with the human rights documents ratified by Argentina and the parliamentary debates on femicide, gender-based violence is the expression of a system of domination that perpetuates inequality between men and women, based on an unequal power relation. Femicide, thus, recognizes a situation of subordination based on an unequal relation of power. For Judge Bloch, however, such power relations cannot be taken for granted in every relationship and must be supported by evidence (Bloch, 2014; Poder Judicial de la Nación, 2018, pp. 396-397).

\subsubsection{Proving 'Hate'}

Another challenging aspect of hate crime is the difficulty to prove the subjective element, which all parties linked to the body of the victim. In line with travesti claims, Judge Báez elaborated on the social construction of trans/travesti bodies, arguing that bodies are social, cultural, and political entities affected by the norms, expectations, and stereotypes of the patriarchal society to which they must conform (Poder Judicial de la Nación,
2018 , p. 200). The asymmetry of power is, in fact, reproduced on bodies, adopting multiple forms and varying from one culture to another. Yet this type of violence "often becomes invisible and naturalized through socialization, disguised as beliefs, legalized by laws, customs, publicity and by stereotypes of masculinity and femininity" (Poder Judicial de la Nación, 2018, p. 201). These dynamics led to "the objectification of the feminine or transsexual body" and thus "women are denied as subjects, subdued, alienated and manipulated. Women or transsexuals lose their individual agency and are subject to men's desire" (Poder Judicial de la Nación, 2018, p. 202). Unfortunately, the judge did not explain how such social policing on travesti bodies could be proved in practice.

Only Judge Bloch focused on the evidence aspect of hate. She provided an inventory of applicable evidentiary means based on the FBI guidelines and the IAC Report, and then analysed the criteria mentioned by the parties and judges. Among the elements indicative of hate crime was the brutality of the crime and signs aiming to erase the victim's identity, (based on the location of the wounds). Judge Bloch confirmed the relevance of the IAC Report as a guiding document and agreed that these criteria should guide the investigation and prosecution of hate crimes (Poder Judicial de la Nación, 2018, p. 342). However, she disagreed that these criteria were met in the specific case, particularly regarding the level of brutality and the placing of the wounds. She considered that the level of violence was not comparable to the examples used in the IAC Report. She did not consider that the wounds on the victim's face, breasts, and buttocks were an attempt to 'erase' her travesti identity either, but were consistent with self-defence signs (Poder Judicial de la Nación, 2018, p. 345). Arguably, the long and detailed discussion on bodies by Judge Baez could have challenged this view if it had focused on the case at hand, making a crucial contribution.

\section{Final Reflections}

Diana Sacayan's trial constituted a means to seek justice for her murder and a unique opportunity to consolidate the right to gender identity and re-voice longstanding demands about the integrity of travesti bodies, access to human rights, and the right to a life without violence. These demands were introduced to the trial through the combination of procedural mechanisms and an overarching conceptual notion. The first procedural measure used was the informal interaction of an ad hoc Commission, composed by family members, trans activists and other allies, and the prosecution office. The second measure was the intervention of Diana's brother and the INADI as auxiliary prosecutors. The third was the incorporation of testimonies of gender/trans experts, activists, and witnesses. Finally, media management during and after the trial, prompted by the Justice Commission, triggered the debate on the murder of travestis, and to a lesser extent, their living conditions. While this article has focused 
on the conceptual aspects of the trial, the procedural aspects would certainly merit further analysis.

The overarching conceptual notion of 'travesticide' was employed to name the murder of travestis and make visible the continuum of violence they face. The idea of a 'continuum' helps to recognize not only the murder but also the violence leading to it, such as the rejection of trans/travesti identities and bodies and the exclusion and denial of their human rights. The structural and institutional nature of such violence becomes clear. The prosecutors introduced the notion and the tribunal unanimously accepted it. The judges disagreed about the possible criminal framing of travesticide, suggesting that different prosecutorial strategies can be devised.

The prosecutorial parties and two judges favoured framing travesticide as hate crime based on gender identity (Article 80.4; Ministerio de Justicia y Derechos Humanos, 2012b). However, such framing raises three issues that claimants should carefully consider. Firstly, the structural nature of the violence is not properly captured by the crime because it focuses on the motive of the accused, that is, their 'aversion' against travestis. Murders appear as incidental, the result of a mad man, despite the prevalence and structural nature of the violence. Secondly, hate crime establishes a high threshold to prove guilt. While the IAC Report can guide in such an attempt, victims' bodies will inevitably become the main piece of evidence. Thus, travesti bodies get scrutinized once again in their death, submitted to a normative examination to find indications of the perpetrator's aversion. Finally, it is unclear if hate crime can capture the intersectional nature of the discrimination against the victims, since, despite all testimonies about the richness of Diana's identity ('trava sudaca originaria' and activist), all discussions ended up focusing on only one aspect: her gender identity.

Judge Bloch argued the notion of 'travesticide' can be criminally framed as gender-based violence against women (Article 80.11 'femicide'; Ministerio de Justicia y Derechos Humanos, 2012b) when the victim is a trans woman or travesti. The tribunal confirmed that trans/travesti women are protected under Article 80.11 since the adoption of the Gender Identity Law. Article 80.11 seems more in line with the structural element of travesticide because it connects it with 'genderbased violence.' That said, their subordinated position requires proof. Moreover, given the legislator's decision to adopt a gender-specific approach ("male perpetrators and female victims"; Ministerio de Justicia y Derechos Humanos, 2012b) the specificity of travesticide is replaced by 'women,' imposing a binary view of the travesti identity. The question remains whether both the feminist and travesti collective would agree to adopt a definition of gender-based violence that focuses on 'genders,' without naming specific gender subjectivities. In any case, the tribunal held that hate crimes and femicide can concur, allowing a more intersectional view of travesti identities.
In sum, Diana Sacayán's trial was a collective achievement that employed effective strategies to unveil trans/travesti experiences, nearing social and institutional recognition and accountability. The complexity of travesticide, however, cannot be properly captured by the current structure of neither hate crimes nor femicide, rendering the criminal response insufficient. These reflections can improve future criminal strategies, and perhaps inform debates prior to the adoption of the new draft of the Criminal Code.

\section{Acknowledgments}

The research for this article was partially carried out at the University of Buenos Aires, with funding from the European Union's Horizon 2020 Research and Innovation Program under the Marie Sklodowska-Curie Grant Agreement No. 793823. The article was finalized at Utrecht University, funded by an NWO grant. I thank Say Sacayán, Yamila Rodriguez, Judge Ivana Bloch, the anonymous reviewers, and the editors for their insightful and constructive comments. I am also extremely grateful to Mina Hunt for her invaluable research support.

\section{Conflict of Interests}

The author declares no conflict of interests.

\section{References}

Acosta Vargas, G. (1999). La mujer en los códigos penales de América Latina y el Caribe Hispano [The woman in the criminal codes of Latin America and Hispanic Caribbean]. In A. Facio \& L. Fries (Eds.), Género y derecho [Gender and law] (pp. 424-472). Santiago: LOM Ediciones.

Berkins, L. (2003). Un itinerario político del travestismo [A political itinerary of travestism]. In D. Maffía (Ed.), Sexualidades migrantes: Género y transgénero [Migrant sexualities: Gender and transgender] (pp. 127-137). Buenos Aires: Editorial Feminaria Editora.

Berkins, L. (2007). Travestis: Una identidad política [Travestis: A political identity]. Emisférica, 4(2). Retrieved from https://hemisphericinstitute.org/en/ emisferica-42/4-2-review-essays/lohana-berkins. html

Berkins, L., \& Fernandez, J. (Eds.). (2005). La gesta del nombre próprio: Informe sobre la situación de la comunidad travesti en la Argentina [The battle for the personal name: Report about the situation of the travesti community in Buenos Aires]. Buenos Aires: Madres de Plaza de Mayo.

Bloch, I. (2014). Estudio crítico del tipo penal de femicidio en el Código Penal argentino [Critical study of the crime of femicide in the Argentinian Criminal Code]. Revista de Derecho Penal, 10, 1996-2011.

Buompadre, J. E. (2013). Los delitos de género en la reforma penal (Ley $\mathrm{N}^{\circ}$ 26.791) [Gender crimes 
in the criminal amendment (Act No. 26.791)]. Pensamiento Penal. Retrieved from http://www. pensamientopenal.com.ar/system/files/2013/02/ doctrina35445.pdf

Cabral Grinspan, M., \& Viturro, P. (2006). (Trans)sexual citizenship in contemporary Argentina. In P. Currah, R. M. Juang, \& S. Minter (Eds.), Transgender rights (pp. 264-273). Minneapolis, MN: University of Minnesota Press.

Celorio, R. M. (2010). The Inter-American court of human rights: Case of González ("Cotton Field") v. Mexico. International Legal Materials, 49(3), 637-761. https:// doi.org/10.5305/intelegamate.49.3.0637

Copeland, L., \& Wolfe, L. R. (1991). Violence against women as bias motivated hate crime: Defining the issues. Washington, DC: Center for Women Policy Studies.

Corte Suprema de Justicia de la Nacion. (2018). Registro nacional de femicidios de la justicia Argentina [National registry of the Argentinian judiciary on femicides]. Buenos Aires: Oficina de la Mujer.

Costa, M. (2014). El pensamiento jurídico feminista en América Latina: Escenarios, contenidos y dilemas [Legal feminist thought in Latin America: Settings, content, dilemmas]. Revista Do Núcleo de Estudos e Pesquisas Em Gênero \& Direito, 3(2).

Craig, K. M. (2002). Examining hate-motivated aggression: A review of the social psychological literature on hate crimes as a distinct form of aggression. $\mathrm{Ag}$ gression and Violent Behaviour, 7(1), 85-101.

de Mauro Rucovsky, M., \& Russell, I. (2019). The travesti critique of the gender identity law in Argentina. TSQ: Transgender Studies Quarterly, 6(2), 223-238. https://doi.org/10.1215/23289252-7348510

Fernández Valle, M. (2018). Las facetas de la justicia [Stages in justice]. In B. Radi \& M. Pecheny (Eds.), Travestis, mujeres transexuales y tribunales: Hacer justicia en la CABA [Travestis, transexual women and courts: Providing justice in the Autonomous City of Buenos Aires] (pp. 49-53). Buenos Aires: Editorial Jusbaires.

Fernández, J. (2003). Los cuerpos del feminismo [Feminism's bodies]. In D. Maffía (Ed.), Sexualidades migrantes: Género y transgénero [Migrant sexualities: Gender and transgender] (p. 138-154). Buenos Aires: Editorial Feminaria Editora.

Figari, R. E. (2018). Homicidio por placer, codicia, odio racial, religioso, de género o a la orientación sexual, identidad de género o su expresión [Manslaughter for pleasure, greed, hate based on race, religion, gender, sexual orientation, gender identity or expression]. Pensamiento Penal.

Gerstenfeld, P. (2004). Hate crimes: Causes, controls, and controversies. Los Angeles, CA: SAGE.

Hall, N. (2013). Hate crime (2nd ed.). New York, NY: Routledge.

Inter-American Commission of Human Rights. (2015). Violence against lesbian, gay, bisexual, trans and intersex persons in the americas (OEA/Ser.L/V/II. Doc.36/15 Rev.2). Washington, DC: Organization of American States.

Jacobs, J., \& Potter, K. (1998). Hate crimes: Criminal law and identity politics. New York, NY: Oxford University Press.

Jamel, J. (2018). Transphobic hate crime. London: Palgrave Macmillan. https://doi.org/10.1007/978-3319-57879-8

Juárez, K. C. (n.d.). Crimen de odio, discurso de odio [Hate crime, hate discourse]. Barcelona: Institut de Drets Humans de Catalunya.

Korol, C. (2018). Cuidar el vuelo lastimado de las mariposas [Tending the injured flight of the butterflies]. In B. Radi \& M. Pecheny (Eds.), Travestis, mujeres transexuales y tribunales: Hacer justicia en la CABA [Travestis, transexual women and courts: Providing justice in the Autonomous City of Buenos Aires] (pp. 61-65). Buenos Aires: Editorial Jusbaires.

Lagarde, M. (2006). Del femicidio al feminicidio [From femicide to feminicide]. Desde El Jardín de Freud, 6, 216-225.

Machuca Rose, M. (2019). Giuseppe Campuzano's afterlife. TSQ: Transgender Studies Quarterly, 6(2), 239-253. https://doi.org/10.1215/232892527348524

Malacalza, L. (2018). “Narcotravestis,” proceso creciente de criminalización de mujeres trans y travestis ['Narcotravestis,' the increasing criminalization process of trans women and travestis]. In B. Radi \& M. Pecheny (Eds.), Travestis, mujeres transexuales y tribunales: Hacer justicia en la CABA [Travestis, transexual women and courts: Providing justice in the Autonomous City of Buenos Aires] (pp. 157-163). Buenos Aires: Editorial Jusbaires.

Mason-Bish, H. (2014). Beyond the silo: Rethinking hate crime and intersectionality. In N. Hall, A. Corb, P. Giannasi, \& J. G. D. Grieve (Eds.), The Routledge international handbook on hate crime (pp. 24-33). Abingdon: Routledge.

Mcphail, B. (2012). Gender-bias hate crimes: A review. In B. Perry (Ed.), Hate and bias crime: A reader (pp. 261-279). New York, NY: Routledge.

Mechanism to Follow Up Convention of Belém do Pará Committee of Experts on Violence. (2008). Declaration on femicide (OEA/Ser.L/II.7.10 MESECVI/CEVI/DEC. 1/08). Washington, DC: Organization of American States.

Meyer, D. (2014). Resisting hate crime discourse: Queer and intersectional challenges to neoliberal hate crime laws. Critical Criminology, 22(1), 113-125. https://doi.org/10.1007/s10612-013-9228-x

Ministerio de Justicia y Derechos Humanos. (2012a). Identidad de genero (Ley 26.743) [Gender identity, Law 26.743]. Buenos Aires: Ministerio de Justicia y Derechos Humanos.

Ministerio de Justicia y Derechos Humanos. (2012b). Codigo penal de la Nacion Argentina [Argentinian 
Criminal Code]. Buenos Aires: Ministerio de Justicia y Derechos Humanos.

Pecheny, M., \& De la Dehesa, R. (2011). Sexualidades y políticas en América Latina: Un esbozo para la discusión [Sexualities and politics in Latin America: An outline for the discussions]. In S. Corrêa \& R. Parker (Eds.), Sexualidade e política na América Latina: Histórias, interseções e paradoxos [Sexuality and politics in Latin America: Stories, interseccions and paradoxes] (pp. 31-79). Rio de Janeiro: Sexuality Policy Watch.

Perry, B. (2012). Accounting for hate crime: Doing difference. In B. Perry (Ed.), Hate and bias crime: A reader (pp. 97-108). New York, NY: Routledge.

Perry, B., \& Alvi, S. (2011). 'We are all vulnerable': The in terrorem effects of hate crimes. International Review of Victimology, 18(1), 57-71. https://doi.org/ $10.1177 / 0269758011422475$

Poder Judicial de la Nación. (2018). Tribunal oral en lo criminal y correccional Nro. 4 de la Capital Federal (CCC 62182/2015/TO1) [Criminal and correctional oral tribunal No. 4 from the city of Buenos Aires]. Buenos Aires: Poder Judicial de la Nación.

Prosecution Unit for Violence Against Women. (2015). Femicidios y homicidio en la Ciudad Autónoma de Buenos Aires [Femicides and murders in Autonomous City of Buenos Aires]. Buenos Aires: Ministerio Público Fiscal de la Nación.

Prosecution Unit for Violence Against Women. (2018). Femicidios y homicidios en la Ciudad Autónoma de Buenos Aires [Femicides and murders in Autonomous City of Buenos Aires]. Buenos Aires: Ministerio Público Fiscal de la Nación.

Radford, J., \& Russell, D. (1994). Femicide: The politics of woman killing. Australian \& New Zealand Journal of Criminology, 27(2). https://doi.org/10.1177/ 000486589402700212

Radi, B., \& Pecheny, M. (Eds.). (2018). Travestis, mujeres transexuales y tribunales: Hacer justicia en la CABA [Travestis, transexual women and courts: Providing justice in the Autonomous City of Buenos Aires]. Buenos Aires: Editorial Jusbaires.

Radi, B., \& Sardá, A. (2016). Travesticidio/transfemicidio [Travesticide/transfemicide]. Boletin Del Observatorio de Género En La Justicia, 9, 28-37.

Rapisardi, F. (2003). Regulaciones políticas: Identidad, diferencia y desigualdad [Political regulations: Identity, difference and inequality]. In D. Maffía (Ed.), Sexualidades migrantes: Género y transgénero [Migrant sexualities: Gender and transgender] (pp. 97-116). Buenos Aires: Editorial Feminaria Editora.

Revista Institucional de la Defensa Pública. (2018). El crimen de Diana Sacayán: Hacia un efectivo reconocimiento del travesticidio/transfemicidio. Entrevista a Mariela Labozzetta [The crime against Di- ana Sacayán: Towards an effective recognition of travesticide/transfemicide. Interview with Mariela Labozzetta]. Revista Institucional de La Defensa Pública de La Ciudad Autónoma de Buenos Aires, 8(14), 335-341.

Rizki, C. (2019). Latin/x American trans studies. TSQ: Transgender Studies Quarterly, 6(2), 145-155. https://doi.org/10.1215/23289252-7348426

Saldivia Menajovsky, L. (2018). El acceso a la justicia de niñxs y adolescentes transgéneros [Access to justice of transgender children and adolescents]. In B. Radi \& M. Pecheny (Eds.), Travestis, mujeres transexuales y tribunales: Hacer justicia en la CABA [Travestis, transexual women and courts: Providing justice in the Autonomous City of Buenos Aires] (pp. 55-60). Buenos Aires: Editorial Jusbaires.

Santana, D. S. (2019). Mais viva!: Reassembling transness, blackness, and feminism [More alive!: Reassembling transness, blackness, and feminism]. TSQ: Transgender Studies Quarterly, 6(2), 210-222. https://doi.org/10.1215/23289252-7348496

Sheffield, C. (1995). Hate violence. In P. Rothenberg (Ed.), Race, class and gender in the United States (pp. 432-441). New York, NY: St. Martin's Press.

Sosa, L. P. A. (2017). Intersectionality in the human rights legal framework on violence against women: At the centre or the margins? Cambridge: Cambridge University Press. https://doi.org/doi:10.1017/ 9781316771525

Sosa, L. P. A., \& Ferrero, M. G. (2018). La prohibición de la violencia simbólica y mediática en la Argentina: ¿Superación de la dicotomía público/privada? [The prohibition of symbolic and media violence in Argentina: Going beyond the public/private dichotomy?]. Revista Electrónica: Instituto de Investigaciones Ambrosio L. Gioja, 20, 1-24.

Viturro, P. (2014). Reflexiones acerca de la ley de identidad de género [Reflexions about the gender identity law]. Boletín Del Observatorio de Género En La Justicia, 4, 14-17.

Wayar, M. (2012). ¿Qué pasó con la T? [What happened to the T?]. Página/12. Retrieved from https://www. pagina12.com.ar/diario/suplementos/soy/1-24362012-05-11.html

Zaffaroni, E. R. (2000). El discurso feminista y el poder punitivo [Feminist discourse and punitive power]. In H. Birgin (Ed.), Las trampas del poder punitivo: El género del derecho penal [The trickery of punitive power: Gender and criminal law] (pp. 19-30). Buenos Aires: Biblos.

Zaffaroni, E. R. (2007, August 21). Los delitos de odio [Hate crimes]. La Gaceta. Retrieved from https:// www.lagaceta.com.ar/nota/231632/tribunales/ delitos-odio-segun-zaffaroni.html 


\section{About the Author}

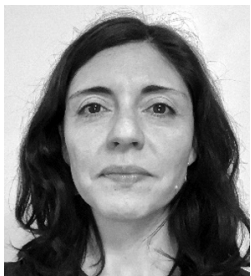

Lorena Sosa is Assistant Professor at the Netherlands Institute of Human Rights (SIM) and is part of the Utrecht Centre for European Research into Family Law (UCERF) at Utrecht University. Her research explores the inclusiveness of human rights law in relation to gender and sexuality in two realms: violence, and equality and non-discrimination. She received a Marie Sklodowska-Curie grant by the European Commission and a VENI by the Dutch Scientific Organisation for her research on gender-based violence against trans and intersex persons. 